\title{
HANDICRAFT AND TECHNOLOGY HANDWERK UND TECHNOLOGIE
}

KLAUS ZWERGER // English translation: Mark Wilch

Excavation finds in China have verified the existence of astounding mortise and tenon joints for $4000 \mathrm{BC}$. The only tools available were stones worked for that purpose. In addition to the Stone Age, other periods have also been cited for materials that elites used for gaining, and staying in, power. Yet it was the artisans who shaped and perfected the tools of war. With their knowledge and experience, they were guaranteed work even when weapons were no longer in demand. Farmers were able to boost their agricultural yields with better implements. Woodworkers were able to improve and refine their products. Frictional wood connections were fundamental elements in highly complex wooden constructions and arose from the interplay between handicraft and technology. Experienced artisans were able to compensate for inferior tools. However, even the best tools can only be shown to advantage in the hands of skilled artisans.

If a product were to endure, artisans had to pour into it their knowledge and experience of specific boundary conditions of climate, topography, or special exposure to destructive forces of nature. Fashion trends as well as economic, social and habitual requirements influenced their work, as did cultural traits.

All these conditions resulted in astonishingly different creations. Here are a few examples to provide fur-
Grabungsfunde in China belegen erstaunliche Loch-Zapfenverbindungen für 4000 v. Chr. Als einzige Werkzeuge standen zugerichtete Steine zur Verfügung. Neben der Steinzeit verdanken auch andere Epochen ihren Namen Materialien, deren Nutzung Eliten dazu diente, ihre Macht zu erringen und zu verteidigen. Doch es waren Handwerker, die Kriegswerkzeuge formten und perfektionierten. Ihr Wissen, ihre Erfahrung verschaffte ihnen auch dann Arbeit, wenn keine Waffen nachgefragt wurden. Bauern konnten mit besserem Werkzeug landwirtschaftliche Erträge steigern. Holzhandwerker konnten ihre Produkte verbessern und verfeinern.

Kraftschlüssige Holzverbindungen als Grundbausteine hochkomplexer Holzkonstruktionen entstanden im Wechselspiel von Handwerk und Technologie. Versierte Handwerker konnten weniger gutes Werkzeug teilweise wettmachen. Das beste Werkzeug kann aber nur in den Händen guter Handwerksleute zur Geltung gebracht werden.

Der Handwerker musste sein Wissen und seine Erfahrung über die je spezifischen Randbedingungen von Klima, Topografie oder besondere Exponiertheit gegenüber zerstörerischen Naturgewalten in ein Produkt einflieBen lassen, wenn es Bestand haben sollte. Modeströmungen, ökonomische, soziale und habituelle Vorgaben beeinflussten seine Arbeit ebenso wie kulturelle Prägungen. 
ther food for thought. Categorizing these examples as Eastern or Western connections is as unsuitable as dividing them into visible connections or connections concealed at the joint. Classification systems created by scientists simplify in inadmissible ways. There is a direct logical correlation between construction and connection technology. Artisans responded in a manner adequate to the specifics of their location. They did not worry about how their work should be classified.

In Europe, structural elements originally fastened with cords or joined with very simple mortise and tenon joints gave way to lap joints for a fairly long time. They had to be worked quite precisely because the accuracy of fit between the male member and female member was there for all to see. Wood is a material with directional cellular formation. Every connection placed at an angle was clearly visible because the change in direction interrupted the homogeneity of the surface texture. Once recognized, this effect could be played with splendidly (Fig. 1).

Skeleton structures in Western construction are inconceivable without diagonal bracing. Fixing the angles of members through triangulation guaranteed the stability of each construction. Braces had to bear up under compressive and tensile loads; wooden nails driven transversely into the joint ensured that they did. However, wooden nails can work their way out of joints as a result of drying processes. They can also be pulled out of their holes if a structural element undergoes extreme twisting. Angled jointing nailing was the carpenters' solution for resisting the whims of the material. Another approach was to refine lap joints in such a way that the tensile and compressive loads
All diese Bedingungen haben zu erstaunlich unterschiedlichen Kreationen geführt. Ein paar Beispiele sollen die Überlegungen weiterführen. Eine Kategorisierung in östliche und westliche Verbindungen taugt dabei genauso wenig wie eine Einteilung in ablesbare oder im Knoten verborgene Verbindungen. Von Wissenschaftlern kreierte Ordnungen simplifizieren unzulässig. Konstruktion und Verbindungstechnologie stehen in einem unmittelbaren logischen Zusammenhang. Der Handwerker hat ortsspezifisch adäquat reagiert. Er hat sich nie den Kopf zerbrochen, wie seine Arbeit einzuordnen ist.

Ursprünglich geschnürte oder mit sehr einfachen Zapfenverbindungen gefügte Konstruktionsteile wichen in Europa für eine geraume Weile Blattverbindungen. Diese mussten sehr exakt ausgeführt werden, weil die Passgenauigkeit von Blatt und Blattsasse für jede*n einsehbar war. Holz ist ein gerichtetes Material. Jede im Winkel angelegte Verbindung sprang den Betrachter*innen ins Auge, weil durch den Richtungswechsel die Homogenität der Oberflächentextur unterbrochen war. Einmal erkannt, ließ sich damit trefflich spielen (Abb. 1).

Skelettbauten sind in der westlichen Bauwelt nicht ohne Diagonalverstrebung denkbar. Die Herstellung winkelstabiler Dreiecke sicherte jeder Konstruktion ihre Stabilität. Streben mussten auf Druck und Zug belastbar sein, quer zur Verbindung eingeschlagene Holznägel stellten das sicher. Holznägel können aber aus Verbindungen "heraustrocknen". Sie können auch durch ein sich extrem verdrehendes Konstruktionselement aus ihrem Loch herausgezogen werden. Schrägnagelung war eine Antwort der Zimmerleute, um den Launen des Materials Widerstand zu leisten. Eine andere Variante war, Blattverbindungen

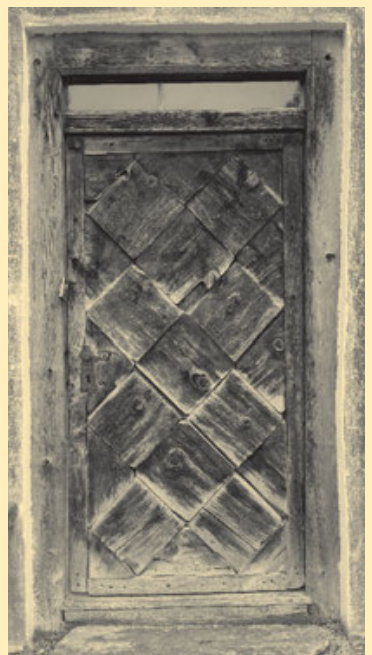

A Fig. 1 | Abb. 1:

Front door of a Tyrolean farmhouse (Austria). 


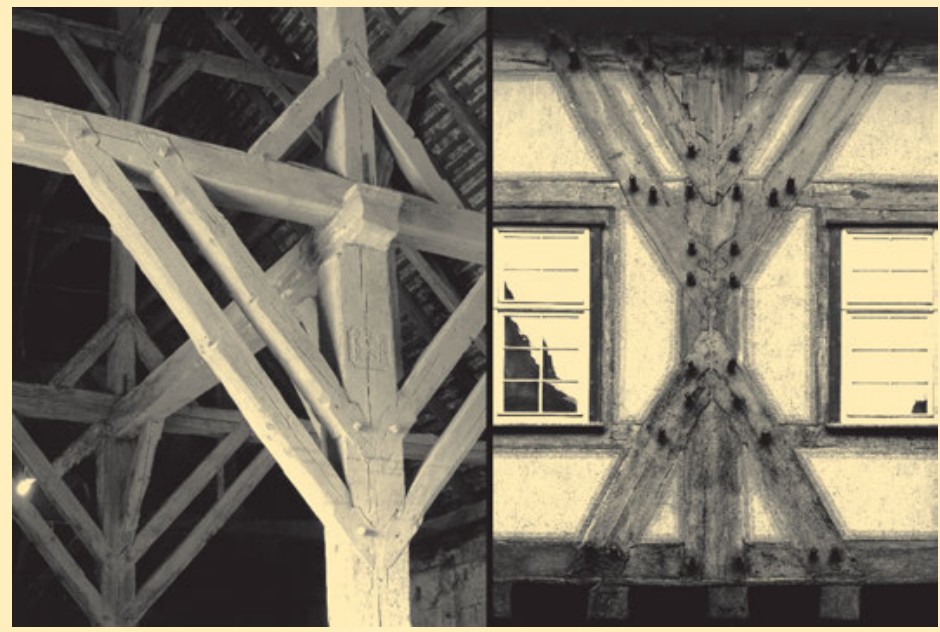

A Fig. 2 | Abb. 2:

The supporting structure for a barn roof in Retz (Austria).

Facade details of the town hall in Esslingen (Germany).

- Fig. 3 | Abb. 3:

Integrated dividing wall in a log cabin in Kramsach (Austria). were countered. The securing wooden nails were then able to relinquish their static function to notches in the outline of the laps (Fig. 2). Thereafter, the sole purpose of the nails was to prevent the structural elements from twisting against each other. An added notch makes the function of this action obvious even to a layperson. The tensile load is distributed between two notches cut side by side rather than being borne by a single notch. The multiplication and evolution of notches into decorative patterns gloss over their function and ultimately cast doubt on it. Very similar developments were evident in log construction as well (Fig. 3). Ultimate$l y$, these two trends have played into each other's hands. If a client wants his architecture to be representational, he is willing to spend a lot of money on it. An artisan who does not have to focus primarily on cost minimization has a chance to show off his skills. His product is always a form of advertising for himself as well.

For a long time, carpenters could count on what seemed to be inexhaustible resources. The larger they built, the more material they used for construction (Fig. 4). A study of historical buildings shows us when and where this principle had to be so zu verfeinern, dass sie Zug- und Druckbelastungen Paroli boten. Damit konnten die sichernden Holznägel ihre statische Funktion an Haken in der Kontur der Blätter abtreten (Abb. 2). Die Nägel sorgten nur noch dafür, dass sich die konstruktiven Elementenichtgegeneinanderverdrehten. Ein eingefügter Haken lässt auch Lai*innen die Funktion der Maßnahme ablesen. Zwei nebeneinander gesetzte Haken entlasten den nur einfachen. Ihre Vervielfachung und Ausformung zu dekorativen Mustern überspielt die Funktion und macht sie letztlich fragwürdig. Sehr ähnliche Entwicklungen ließen sich im Blockbau beobachten (Abb. 3). Zwei Tendenzen spielen einander in die Hände. Wenn der Auftraggeber mit seiner Architektur repräsentieren will, ist er bereit, dafür viel Geld auszugeben. Handwerksleute, die nicht vorrangig an Kostenminimierung denken müssen, haben die Chance zu zeigen, was sie können. Ihr Produkt ist immer auch Werbeträger.

Für eine lange Zeit konnten sich Zimmerleute auf vermeintlich unerschöpfliche Ressourcen verlassen. Je größer sie bauten, desto mehr Material verbauten sie (Abb. 4). Das Studium historischer Bauten zeigt uns, wann wo ein Umdenkprozess eingeleitet werden musste. Die Namen von Bauepochen dienen als Schubladen, in denen Veränderungen schematisch zusammengefasst werden. Referenzbeispiele unterschiedlicher Epochen zeigen besonders anschaulich, wie Handwerksleute neue Technologien entwickelten, um auftretende Probleme zu überwinden (Abb. 5). Materialverknappung und der Anspruch, immer größere Weiten stützenlos zu überspannen, erforderten zunehmend komplexeres Wissen von Spezialisten.

Mit Beispielen aus Ostasien soll das Spektrum erweitert werden. Auch dort war Holzmangel ein Innovationsmotor. 


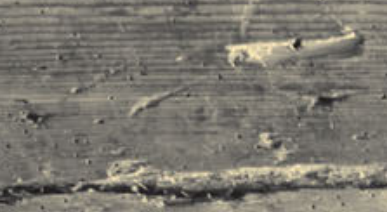

-

3

minescise

ब.

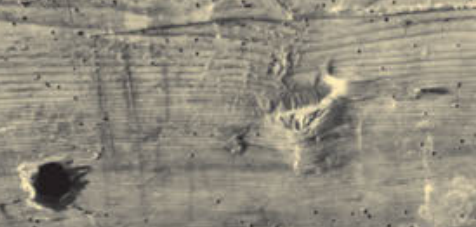

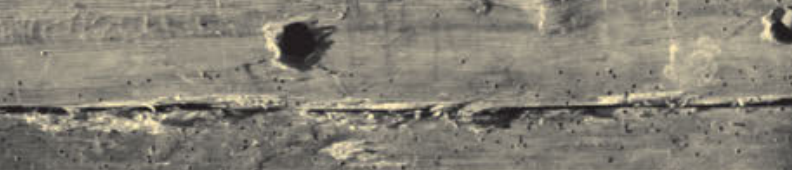

(1)

\section{c}

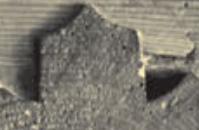

15

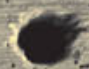

(in

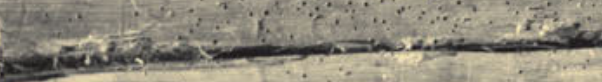

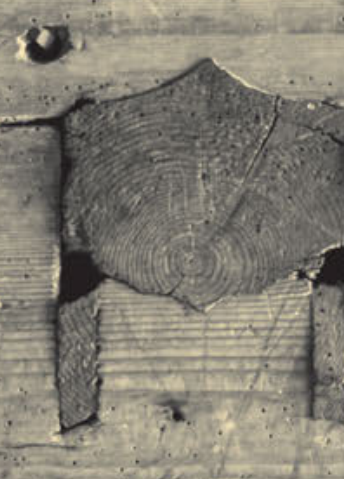

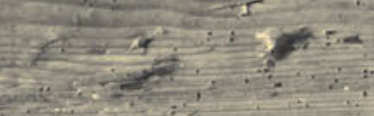

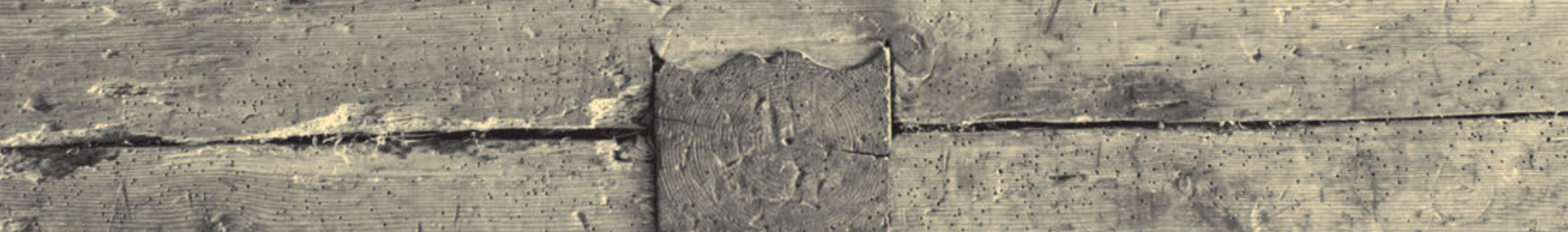

$x^{2} x^{2} x^{2}$

$+\frac{1}{2}$

$x=$

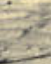

3

20 5

\section{1.}

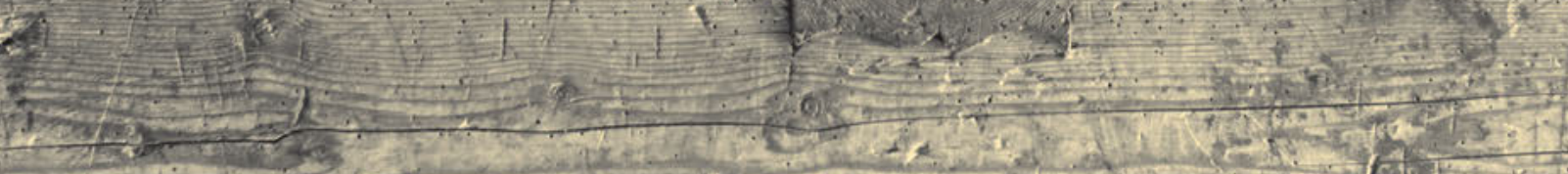




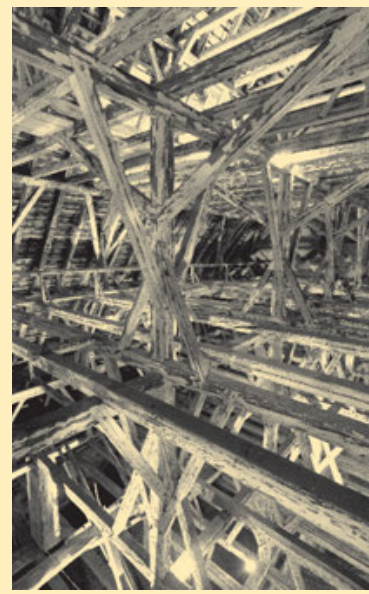

A Fig. 4 | Abb. 4:

The five-story Gothic roof truss built by Thomas Schweinebacher from 1503 to 1518 in Schwaz (Austria).

reassessed. The names of architectural eras serve as filing drawers for grouping these changes in a schematic way. Reference examples from different periods vividly show how artisans developed new technologies to overcome arising problems (Fig. 5). Material shortages and the aspiration to span ever-larger expanses without support required increasingly more complex knowledge from experts.

The following examples from East Asia are meant to expand the spectrum. There, too, a shortage of wood became a driver of innovation. And there were others. In some regions, statically and structurally effective connections had to be better protected from water absorption; in other regions, they had to withstand regularly recurring typhoons with wind

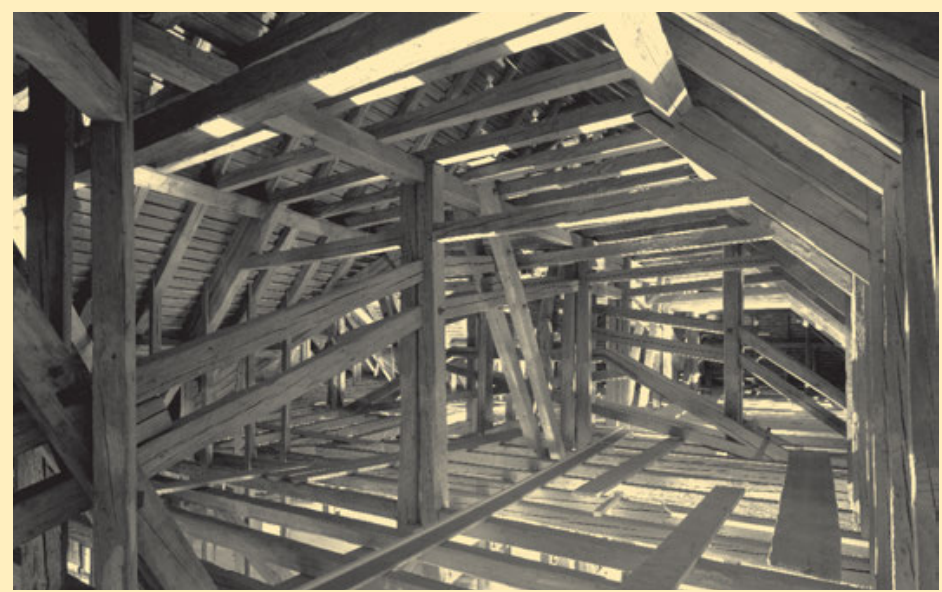

$\Delta$ Fig. 5 | Abb. 5:

With the hanging truss roof structure he built from 1764 to 1767 in a church in Wädenswil (Switzerland), Hans Ulrich Grubenmann succeeded in keeping the 21 meters by 36 meters oratory free of columns. speeds of around $200 \mathrm{~km} / \mathrm{h}$; still elsewhere they had to make it through earthquakes intact. Many historical wooden buildings have demonstrated impressive proof of their resilience, having withstood multiple natural disasters in the past (Fig. 6).

In situations where the effective parts of a connection are shifted to the inside of the assembly to protect them from excessive relative humidity and at the same time, the visible texture is supposed to repel or drain
Es gab noch andere. Die statisch und konstruktiv wirksamen Verbindungen mussten in manchen Regionen besser gegen Wasseraufnahme geschützt werden, in manchen Regionen regelmäßig wiederkehrenden Taifunen mit Windgeschwindigkeiten um die $200 \mathrm{~km} / \mathrm{h}$ widerstehen können und andernorts Erdbeben heil überstehen. Manche historische Holzbauten stellen eindrucksvoll unter Beweis, dass sie mehrfach Naturkatastrophen standhalten konnten (Abb. 6).

Wenn die wirksamen Teile einer Verbindung zu ihrem Schutz gegen zu hohe Luftfeuchtigkeit in ihr Inneres verlegt werden und zugleich die ablesbare Textur möglichst wasserabweisend oder -ableitend sein soll, können Handwerksleute nicht mehr durch komplexe Oberflächen beeindrucken. Ganz im Gegenteil muss das Augenmerk auf geschlossenen Holzzellen und Verbindungsknoten liegen, die eine Wasseraufnahme tunlichst unterbinden. Wenn der funktionelle Teil der Verbindung in seinem Volumen eingeschränkt ist, muss die Ausführung umso exakter ausfallen, werden doch die Kräfte einer Verbindungshälfte über Kontaktflächen auf die andere übertragen. Je weniger Spiel sie haben, je unmittelbarer Kräfte transportiert werden, desto besser ist die Verbindung. Durch fortschreitende Miniaturisierung und gleichzeitige Vervielfachung von wirksamen Haken, Stufen und Absätzen versuchten die Zimmerleute Lastanfälle möglichst breit gefächert zu verteilen (Abb. 7).

Wichtigste Voraussetzung für die Umsetzung solch anspruchsvoller Ideen waren extrem gut schärfbare Schneidwerkzeuge. Diese wiederum beförderten die Entwicklung noch besserer Verbindungen. Mangelhaftes Wissen um Eigenschaften und Qualitäten des verarbeiteten Materials kann durch 
off water as effectively as possible, artisans can no longer impress the world with complex surfaces. On the contrary, they must concentrate on closed wood cells and connection joints that prevent water absorption to the greatest possible extent. If the functional part of the connection is subject to volume constraints, it must be worked all the more accurately. After all, the forces from one half of the connection are transferred via the contact surfaces to the other half. The less play there is between them and the more directly the forces are transferred, the better the connection is. Carpenters sought to distribute the arising loads as diversely as possible through progressive miniaturization and a simultaneous multiplication of effective notches, steps and recesses (Fig. 7).

To implement these sophisticated ideas, it was crucial to possess cutting tools that could be sharpened extremely well. They, in turn, encouraged the development of even better connections. But not even the best tools can make up for a lack of knowledge about the properties and qualities of the material being worked. Two further examples show what incredible advances knowledge can lead to. In houses around Mount Haku in Japan, one finds numerous connecting joints that all follow one idea. The horizontal construction elements such as beams and braces are mortised into a column or laid onto the column's peg-like top end featuring stepped recesses (Fig. 8). One is struck by the audacity of perforating a bearing column so extensively. The multi-recessed top end of the column is at least as significant. This top end bears the most massive beams that serve as horizontal bracing underneath the roof construction and bear that construction. The area gets four to five meters of snow cover

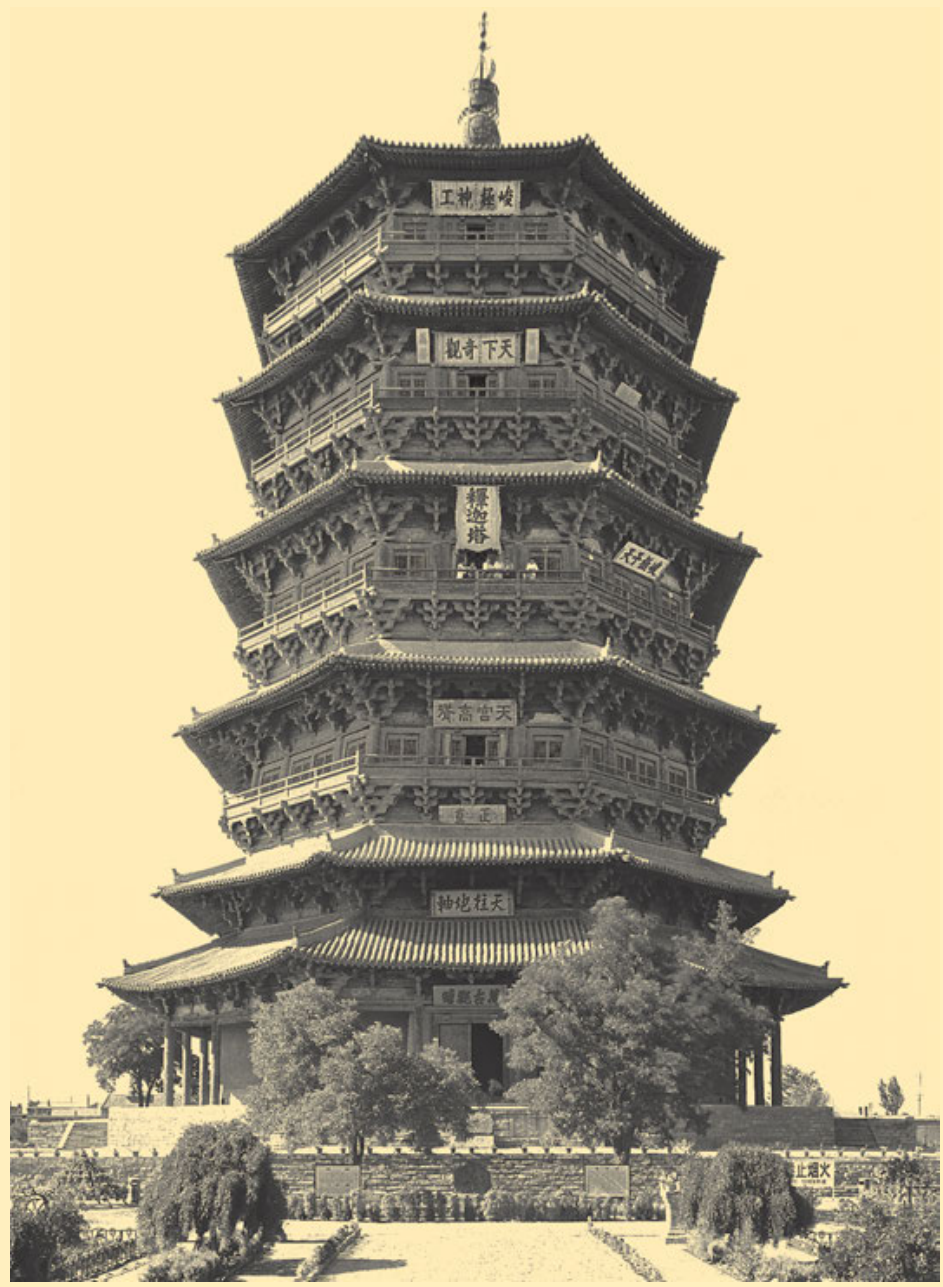

das beste Werkzeug nicht kompensiert werden. Zwei weitere Beispiele zeigen, zu welch unglaublichen Entwicklungen Wissen führen kann. In Häusern um den Berg Haku (Japan) hat man zahlreiche Verbindungsknoten gefunden, die alle einer Idee folgen. Die horizontalen Konstruktionselemente wie Balken und Verstrebungen werden in eine Säule eingezapft bzw. dem stufenförmig abgesetzten zapfenförmigen oberen Ende der Säule aufgelegt (Abb. 8). Der Wagemut, die tragende Säule so stark zu perforieren, springt ins Auge. Wenigstens ebenso bedeutsam ist das mehrfach abgesetzte obere Säulenende. Es trägt die massivsten Balken, die der horizontalen
$\Delta$ Fig. 6 | Abb. 6:

The Sakyamuni Pagoda at the Fogong Temple was built in Ying County in Shanxi Province (China) in 1056. It has survived several major earthquakes despite being 67 meters high. 


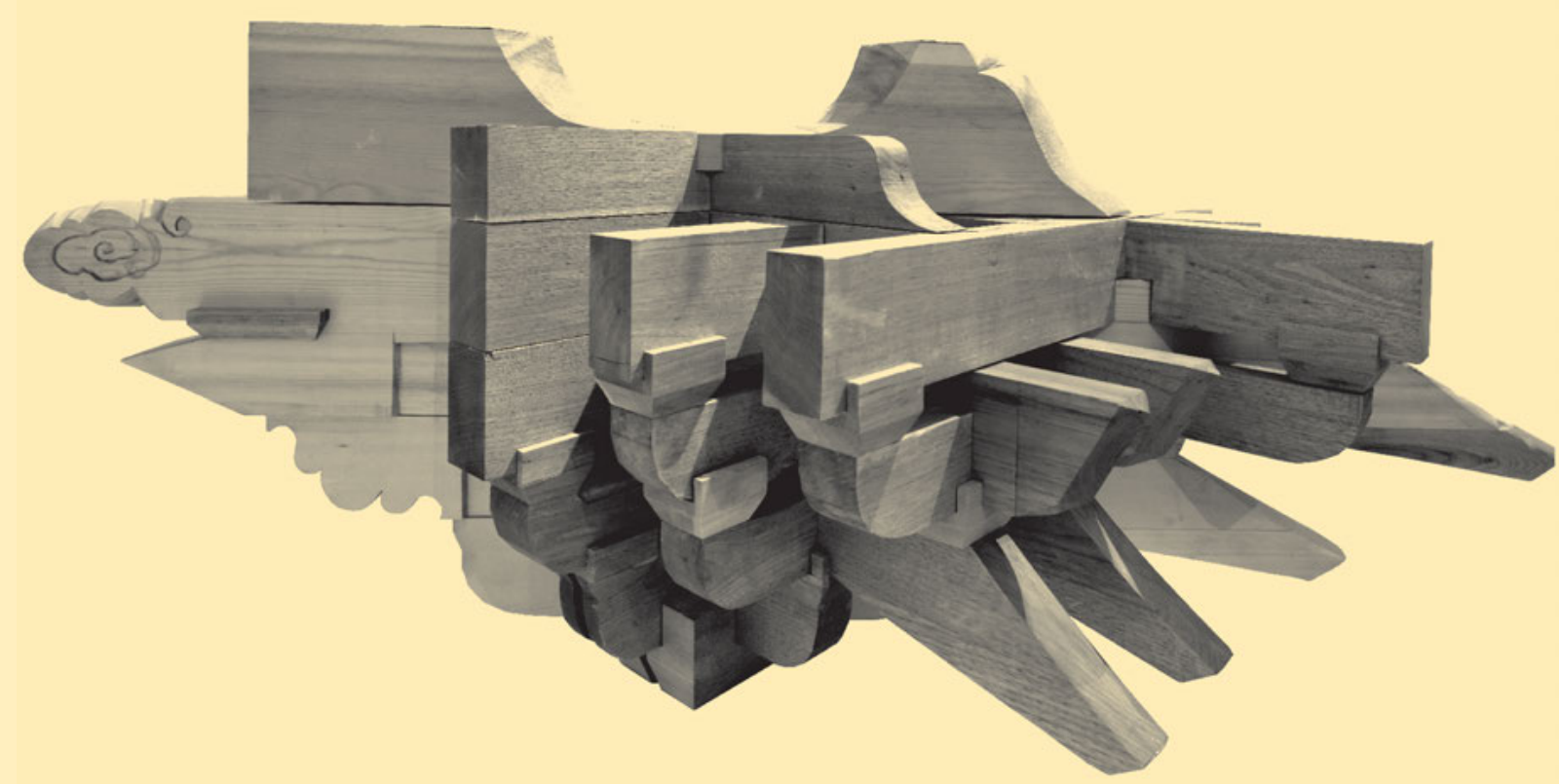

A Fig. 7 | Abb. 7:

A carpentry workshop at the Forbidden City in Beijing built this dougong model for the exhibition The Mystery of Wood in Stainz, Austria (2014-2015). for up to six months a year. Thanks to very tall trees that were available locally, carpenters were able to develop a building technique that met all the specific requirements posed by such extreme climatic conditions. They made full use of the elasticity of the material. Mortises never take up more than one third of the cross section. This guarantees sufficiently cohesive wood fibers even under extreme loading.

The Naxi of Northwest Yunnan in China have developed a building technique that withstands the numerous earthquakes that occur in that region. They too have fully utilized the elastic potential of wood, but the tools they had at their disposal were far less precise. For this reason, they slotted the purlin-bearing columns very deeply all the way to the lowest beam in the roof construction. The horizontal beams are reduced in width to a point where they fit into the forked column (Fig. 9). In the event of extreme fluctuations, the massive cross section of the beams works as a lever that
Aussteifung unterhalb der Dachkonstruktion dienen bzw. diese tragen. Die Gegend liegt für bis zu sechs Monate unter vier bis fünf Metern Schnee. Die Zimmerleute konnten dank lokal verfügbarer, sehr hoch gewachsener Bäume eine Bautechnologie entwickeln, die all den spezifischen Anforderungen Rechnung trug, die mit solch extremen klimatischen Bedingungen einhergingen. Sie reizten die Elastizität des Materials maximal aus. Zapfenlöcher beanspruchen nie mehr als ein Drittel des Querschnitts. Das garantiert auch bei Extrembelastung ausreichend zusammenhängende Holzfasern.

Die im Nordwesten Yunnans lebenden Naxi haben eine Bautechnologie entwickelt, die den zahlreichen Erdbeben standhält. Auch sie schöpften das Potenzial der Elastizität von Holz voll aus, mussten aber auf weit weniger präzises Werkzeug zurückgreifen. Daher schlitzten sie die pfettentragenden Säulen sehr tief bis zum untersten Balken der Dachkonstruktion. Die horizontalen Balken werden im Knoten so stark reduziert, dass sie in 

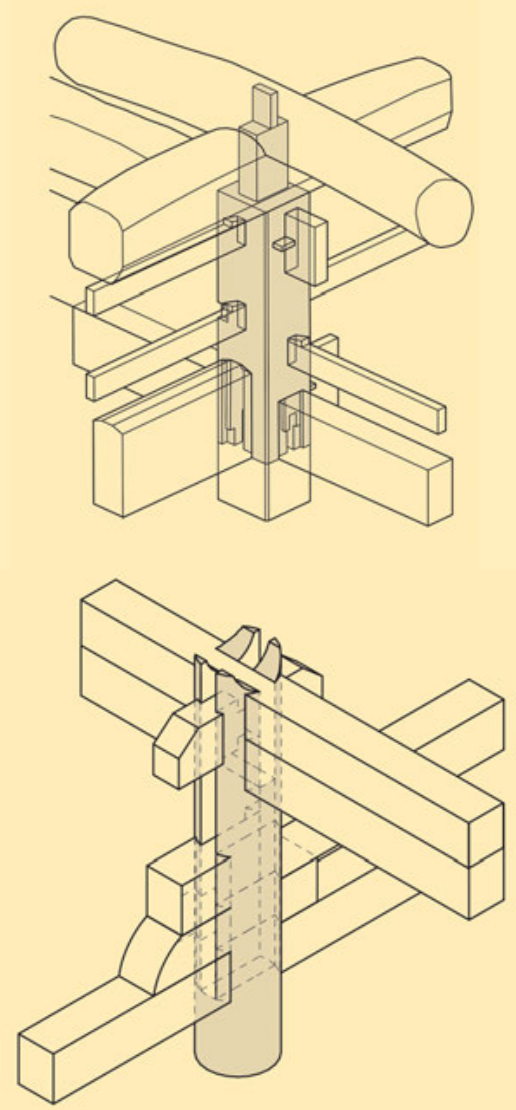

would inevitably crack the slotted column. To prevent this effect, the cross-section reduction is not incised at right angles. The beam cheeks to the left and right of the column envelope the column, thereby keeping the slot from being spread apart. In addition, there are always beams fitted in an orthogonal arrangement in the column, which greatly reduces the play of this lever effect on the slotted column while also providing a bearing surface for further beams in the slot.

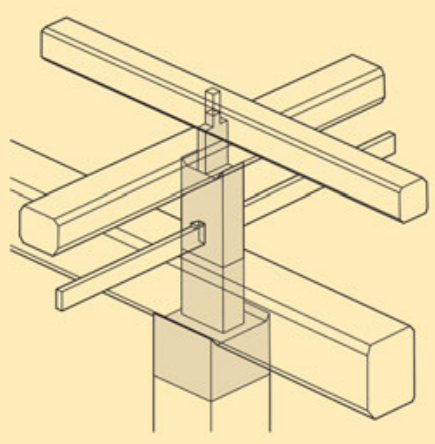

Fig. 8 | Abb. 8:

Joint details for load-bearing columns in a minka (a traditional Japanese house) located in the mountainous landscape between Ishikawa and Gifu (Japan). Drawing from: Fukui Uyô, Tsukidate Toshiei: Mono iu Shiguchi Hakusanroku de atsumeta minka no kakera, Tokyo: LIXIL-Shuppan, 2019: 7, 21.

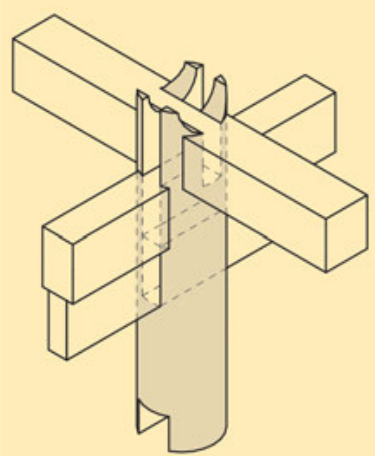

die Säule eingehälst werden können (Abb. 9). Der massive Querschnitt der Balken wirkt im Fall extremer Schwankungen als Hebel, der die geschlitzte Säule sprengen müsste. Zur Verhinderung dieses Effekts ist die Querschnittsreduktion nicht rechtwinkelig eingeschnitten. Die Balkenwangen links und rechts der Säule umgreifen die Säule und sperren solchermaßen die Aufspreizung des Schlitzes. Zusätzlich gibt es immer orthogonal eingehälste Balken, die den Spielraum der erwähnten Hebelwirkung auf die geschlitzte Säule stark reduzieren und zugleich Auflage für weitere Balken im Schlitz sind.
4Fig. 9 | Abb. 9:

Carpenters belonging to the Naxi, an ethnic minority in Yunnan (China), developed joint details such as these to withstand the massive earthquakes that occur in the region.

Drawing: Meng Yang 